\title{
Effect of Laser Rapid Sintering on the Electrical Properties of Sr- and $\mathrm{Mg}$-doped $\mathrm{LaGaO}_{3}$
}

\author{
Jie Zhang ${ }^{1, \text { a }}$, Hairong $\mathrm{Gao}^{2, \mathrm{~b}}$ Chenggang $\mathrm{Li}^{1, \mathrm{c}}$, Ya'nan Tang ${ }^{1, \mathrm{~d}}$ and Chao Yuan ${ }^{3, \mathrm{e}}$ \\ ${ }^{1}$ College of Physics and Electronic Engineering, Zhengzhou Normal University, Zhengzhou \\ 450044, China \\ ${ }^{2}$ College of Chemistry and Chemical Engineering, Zhengzhou Normal University, Zhengzhou \\ 450044, China \\ ${ }^{3}$ College of Science, Henan Agricultural University, Zhengzhou 450002, China \\ ajiezhang76@126.com, bgaohairong2004@163.com, 'scu_lcg@163.com, ${ }^{\mathrm{d}}$ airland_boy@163.com \\ ezhidaoliao1902@sina.cn
}

Keywords: Solid oxide fuel cells (SOFCs); Laser rapid sintering (LRS); Solid state reaction (SSR); Microstructure; Electrical properties.

Abstract. Materials $\mathrm{La}_{0.9} \mathrm{Sr}_{0.1} \mathrm{Ga}_{0.8} \mathrm{Mg}_{0.2} \mathrm{O}_{3-\delta}$ and $\mathrm{La}_{0.8} \mathrm{Sr}_{0.2} \mathrm{Ga}_{0.83} \mathrm{Mg}_{0.17-\mathrm{x}} \mathrm{Co}_{\mathrm{x}} \mathrm{O}_{3-\delta}$ with $\mathrm{x}=0,0.05,0.085$, 0.10 and 0.15 are synthesized by laser rapid sintering (LRS). It is found that the total conductivities of $\mathrm{La}_{0.8} \mathrm{Sr}_{0.2} \mathrm{Ga}_{0.83} \mathrm{Mg}_{0.17-\mathrm{x}} \mathrm{Co}_{\mathrm{x}} \mathrm{O}_{3-\delta}$ by LRS are obviously improved by Co doping, showing a general increase with the content $\mathrm{Co}$ except that for $\mathrm{x}=0.15$. The conductivities of the $\mathrm{La}_{0.9} \mathrm{Sr}_{0.1} \mathrm{Ga}_{0.8} \mathrm{Mg}_{0.2} \mathrm{O}_{3-\delta}$ and $\mathrm{La}_{0.8} \mathrm{Sr}_{0.2} \mathrm{Ga}_{0.83} \mathrm{Mg}_{0.085} \mathrm{Co}_{0.085} \mathrm{O}_{3-\delta}$ samples synthesized by LRS are superior to those of both samples for the same compositions by solid state reaction (SSR) at any temperatures. The conductivities of $\mathrm{La}_{0.9} \mathrm{Sr}_{0.1} \mathrm{Ga}_{0.8} \mathrm{Mg}_{0.2} \mathrm{O}_{3-\delta}$ and $\mathrm{La}_{0.8} \mathrm{Sr}_{0.2} \mathrm{Ga}_{0.83} \mathrm{Mg}_{0.085} \mathrm{Co}_{0.085} \mathrm{O}_{3-\delta}$ samples synthesized by LRS are about twice and thrice as much as those of the samples for the same compositions synthesized by SSR, respectively. The improved conductivities of $\mathrm{La}_{0.9} \mathrm{Sr}_{0.1} \mathrm{Ga}_{0.8} \mathrm{Mg}_{0.2} \mathrm{O}_{3-\delta}$ and $\mathrm{La}_{0.8} \mathrm{Sr}_{0.2} \mathrm{Ga}_{0.83} \mathrm{Mg}_{0.085} \mathrm{Co}_{0.085} \mathrm{O}_{3-\delta}$ prepared by laser rapid sintering with respect to that by solid state reactions for the same composition is attributed to the unique microstructures of the samples generated during laser rapid sintering.

\section{Introduction}

The perovskite oxide, strontium- and magnesium-doped $\mathrm{LaGaO}_{3}$ (LSGM), exhibits a higher ionic conductivity $\left(\sim 0.10 \mathrm{~S} \mathrm{~cm}^{-1}\right.$ at $\left.800^{\circ} \mathrm{C}\right)[1,2]$ than conventional YSZ over a wide range of oxygen partial pressure. These superior electrical and stable properties make $\mathrm{Sr}$ - and $\mathrm{Mg}$-doped $\mathrm{LaGaO}_{3}$ (LSGM) the most promising candidates as electrolytes for intermediate temperature SOFCs. LSGM powders were generally synthesized by solid state reactions (SSR)[3-5] or wet chemical routes [6-9]. However, the synthesis of a pure single phase material of LSGM is a rather difficult task. Therefore, it is necessary to explore new and rapid synthetic methods. In a previous study, we developed a new laser rapid solidification (LRS) to synthesize $\mathrm{La}_{0.9} \mathrm{Sr}_{0.1} \mathrm{Ga}_{0.8} \mathrm{Mg}_{0.2} \mathrm{O}_{2.85}$ electrolyte [10]. It has been proved that $\mathrm{Sr}$ - and $\mathrm{Mg}$-doped $\mathrm{LaGaO}_{3}$ with other compositions can also been synthesized by this technology. Furthermore the samples prepared by LRS exhibit much higher electrical conductivity with respect to the LSGMs by SSR. In this paper, the effect of laser rapid sintering on the electrical properties of Srand $\mathrm{Mg}$-doped $\mathrm{LaGaO}_{3}$ has been analyzed.

\section{Experiment}

$\mathrm{La}_{0.9} \mathrm{Sr}_{0.1} \mathrm{Ga}_{0.8} \mathrm{Mg}_{0.2} \mathrm{O}_{3-\delta}$ and $\mathrm{La}_{0.8} \mathrm{Sr}_{0.2} \mathrm{Ga}_{0.83} \mathrm{Mg}_{0.17-\mathrm{x}} \mathrm{Co}_{\mathrm{x}} \mathrm{O}_{3-\delta}(\mathrm{x}=0,0.05,0.085,0.10,0.15)$ samples were prepared with starting materials of $\mathrm{La}_{2} \mathrm{O}_{3}(99.99 \%), \mathrm{Ga}_{2} \mathrm{O}_{3}(99.99 \%), \mathrm{SrCO}_{3}(99 \%), \mathrm{MgO}(98 \%)$ and and $\mathrm{Co}_{2} \mathrm{O}_{3}$ (99.9\%). Two series of $\mathrm{La}_{0.9} \mathrm{Sr}_{0.1} \mathrm{Ga}_{0.8} \mathrm{Mg}_{0.2} \mathrm{O}_{3-\delta}$ samples were prepared by high-temperature solid state reactions and laser rapid sintering, respectively. Five series of $\mathrm{La}_{0.8} \mathrm{Sr}_{0.2} \mathrm{Ga}_{0.83} \mathrm{Mg}_{0.17-\mathrm{x}} \mathrm{Co}_{\mathrm{x}} \mathrm{O}_{3-\delta}(\mathrm{x}=0,0.05,0.085,0.10,0.15)$ samples were prepared by laser rapid sintering, for comparison the $\mathrm{La}_{0.8} \mathrm{Sr}_{0.2} \mathrm{Ga}_{0.83} \mathrm{Mg}_{0.085} \mathrm{Co}_{0.085} \mathrm{O}_{3-\delta}$ sample was synthesized by 
high-temperature solid state reactions. The high-temperature solid state reactions were carried out with pressed pellets by calcinating at $1250^{\circ} \mathrm{C}$ for $10 \mathrm{~h}$ and then sintering at $1500^{\circ} \mathrm{C}$ for $6 \mathrm{~h}$ and at $1600^{\circ} \mathrm{C}$ for $2 \mathrm{~h}$ with intermediate grindings (denoted as SSR), respectively. The laser rapid sintering (LRS) was performed by using a $5 \mathrm{~kW}$ continuous-wave $\mathrm{CO}_{2}$ laser and the method was described in detail previously [10]. The optimized synthesis conditions are $1100 \mathrm{~W}$ laser power and $1 \mathrm{mms}^{-1}$ scan speed. The samples were analyzed by XRD with an X'Pert PRO X-Ray Diffractometer. The electrical conductivities were measured in air as a function of temperature $\left(250-950^{\circ} \mathrm{C}\right)$ by AC impedance spectra with Pastat 2273 (Princeton Applied Research). The range of ac frequency is $0.1 \mathrm{~Hz}-10^{6} \mathrm{~Hz}$. Platinum paste was fired on opposite sides of the pellets as the electrodes.

\section{Results and Discussions}

Phase Composition. Figure $1 \mathrm{a}$ and $1 \mathrm{~b}$ show the XRD patterns of $\mathrm{La}_{0.9} \mathrm{Sr}_{0.1} \mathrm{Ga}_{0.8} \mathrm{Mg}_{0.2} \mathrm{O}_{3-\delta}$ powders synthesized by solid state reaction at respectively $1250^{\circ} \mathrm{C}$ for $10 \mathrm{~h}, 1500^{\circ} \mathrm{C}$ for $6 \mathrm{~h}$ and $1600^{\circ} \mathrm{C}$ for $2 \mathrm{~h}$ (Fig.1a, denoted as 9182-SSR) and laser rapid sintering with $1100 \mathrm{~W}$ laser powers at $1 \mathrm{mms}^{-1} \mathrm{scan}$ speed (Fig.1b, denoted as 9182-LRS). It can been seen that the pure $\mathrm{La}_{0.9} \mathrm{Sr}_{0.1} \mathrm{Ga}_{0.8} \mathrm{Mg}_{0.2} \mathrm{O}_{3-\delta}$ phase can be obtained by SSR and LRS. Figure 1c 1g show the XRD patterns of $\mathrm{La}_{0.8} \mathrm{Sr}_{0.2} \mathrm{Ga}_{0.83} \mathrm{Mg}_{0.17-\mathrm{x}} \mathrm{Co}_{\mathrm{x}} \mathrm{O}_{3-\delta}$ with different compositions prepared by laser rapid sintering with $1100 \mathrm{~W}$ laser powers at $1 \mathrm{mms}^{-1}$ scan speed for (c) $\mathrm{x}=0$; (d) $\mathrm{x}=0.05$; (e) $\mathrm{x}=0.085$; (f) $\mathrm{x}=0.10$; (g) $\mathrm{x}=0.15$. For comparison the XRD pattern of $\mathrm{La}_{0.8} \mathrm{Sr}_{0.2} \mathrm{Ga}_{0.83} \mathrm{Mg}_{0.085} \mathrm{Co}_{0.085} \mathrm{O}_{3-\delta}$ sample by SSR $\left(1250^{\circ} \mathrm{C}\right.$ for $10 \mathrm{~h}, 1500^{\circ} \mathrm{C}$ for $6 \mathrm{~h}$ and $1600^{\circ} \mathrm{C}$ for $2 \mathrm{~h}$ ) is also shown in $1 \mathrm{~h}$. It shows that with optimized synthesis conditions the series of $\mathrm{La}_{0.8} \mathrm{Sr}_{0.2} \mathrm{Ga}_{0.83} \mathrm{Mg}_{0.17-\mathrm{x}} \mathrm{Co}_{\mathrm{x}} \mathrm{O}_{3-\delta}$ materials can be successfully synthesized by LRS except the one with $\mathrm{x}=0.15$ which contains a little amount of a secondary phase of $\mathrm{LaSrGa}_{3} \mathrm{O}_{7}$.

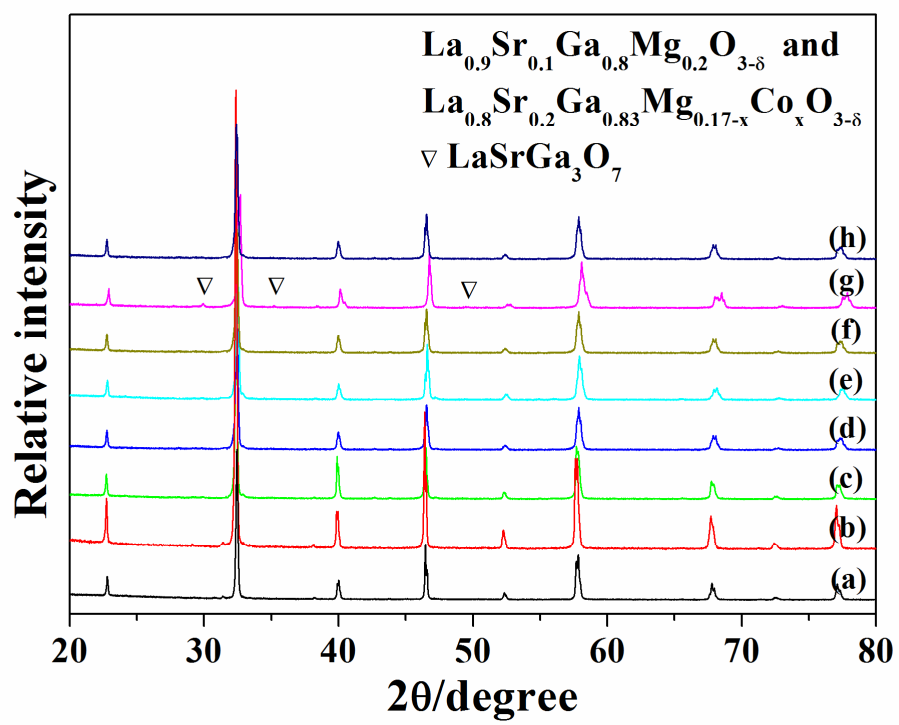

Figure 1. XRD patterns of $\mathrm{La}_{0.9} \mathrm{Sr}_{0.1} \mathrm{Ga}_{0.8} \mathrm{Mg}_{0.2} \mathrm{O}_{3-\delta}$ powders synthesized by (a) solid state reaction at respectively $1250^{\circ} \mathrm{C}$ for 10

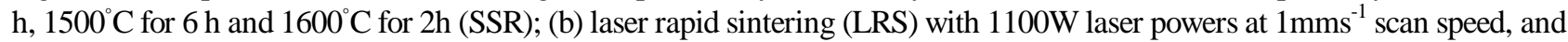

$\mathrm{La}_{0.8} \mathrm{Sr}_{0.2} \mathrm{Ga}_{0.83} \mathrm{Mg}_{0.17-x} \mathrm{Co}_{x} \mathrm{O}_{3-\delta}$ samples by LRS; (c) $\mathrm{x}=0$; (d) $\mathrm{x}=0.05$; (e) $\mathrm{x}=0.085$; (f) $\mathrm{x}=0.10$; (g) $\mathrm{x}=0.15$ and (h) $\mathrm{La}_{0.8} \mathrm{Sr}_{0.2} \mathrm{Ga}_{0.83} \mathrm{Mg}_{0.085} \mathrm{Co}_{0.085} \mathrm{O}_{3-\delta}$ sample by SSR.

Electrical Properties. The total conductivities plots of $\mathrm{La}_{0.9} \mathrm{Sr}_{0.1} \mathrm{Ga}_{0.8} \mathrm{Mg}_{0.2} \mathrm{O}_{3-\delta}$ synthesized by SSR (2a) and LRS (2b) are shown in Figure 2. It can be seen that the conductivities of $\mathrm{La}_{0.9} \mathrm{Sr}_{0.1} \mathrm{Ga}_{0.8} \mathrm{Mg}_{0.2} \mathrm{O}_{3-\delta}$ synthesized by LRS (2b) are much higher than those of the samples synthesized by solid state reactions (2a) with the same composition at any temperatures. The conductivities of $\mathrm{La}_{0.9} \mathrm{Sr}_{0.1} \mathrm{Ga}_{0.8} \mathrm{Mg}_{0.2} \mathrm{O}_{3-\delta}$ synthesized by LRS (2b) are $0.027,0.079$ and $0.134 \mathrm{Scm}^{-1}$ measured at 600,700 and $800^{\circ} \mathrm{C}$, respectively, while the conductivities of $\mathrm{La}_{0.9} \mathrm{Sr}_{0.1} \mathrm{Ga}_{0.8} \mathrm{Mg}_{0.2} \mathrm{O}_{3-\delta}$ synthesized by SSR (2a) are $0.019,0.034$ and $0.041 \mathrm{Scm}^{-1}$. Figure 
2c $2 \mathrm{~h}$ show the total conductivities of the $\mathrm{La}_{0.8} \mathrm{Sr}_{0.2} \mathrm{Ga}_{0.83} \mathrm{Mg}_{0.17-\mathrm{x}} \mathrm{Co}_{\mathrm{x}} \mathrm{O}_{3-\delta}$ samples with different compositions prepared by laser rapid sintering with $1100 \mathrm{~W}$ laser powers at $1 \mathrm{mms}^{-1}$ scan speed for (c) $\mathrm{x}=0$; (d) $\mathrm{x}=0.05$; (e) $\mathrm{x}=0.085$; (f) $\mathrm{x}=0.10$; (g) $\mathrm{x}=0.15$ and (h) $\mathrm{La}_{0.8} \mathrm{Sr}_{0.2} \mathrm{Ga}_{0.83} \mathrm{Mg}_{0.085} \mathrm{Co}_{0.085} \mathrm{O}_{3-\delta}$ sample by SSR. It is obvious that the total conductivities of $\mathrm{La}_{0.8} \mathrm{Sr}_{0.2} \mathrm{Ga}_{0.83} \mathrm{Mg}_{0.17-\mathrm{x}} \mathrm{Co}_{\mathrm{x}} \mathrm{O}_{3-\delta}$ by $\mathrm{LRS}$ are obviously improved by Co doping, showing a general increase with the content Co except that for $\mathrm{x}=0.15$. The total conductivity of $\mathrm{La}_{0.8} \mathrm{Sr}_{0.2} \mathrm{Ga}_{0.83} \mathrm{Mg}_{0.085} \mathrm{Co}_{0.085} \mathrm{O}_{3-\delta}$ prepared by LRS reaches $0.067,0.124$ and 0.202 $\mathrm{Scm}^{-1}$ at 600,700 and $800^{\circ} \mathrm{C}$, respectively, being much higher than the corresponding values $(0.026,0.065$ and $0.105 \mathrm{Scm}^{-1}$ ) of the same composition prepared by SSR.

From figure 2 it is found that the conductivities of the $\mathrm{La}_{0.9} \mathrm{Sr}_{0.1} \mathrm{Ga}_{0.8} \mathrm{Mg}_{0.2} \mathrm{O}_{3-\delta}$ and $\mathrm{La}_{0.8} \mathrm{Sr}_{0.2} \mathrm{Ga}_{0.83} \mathrm{Mg}_{0.085} \mathrm{Co}_{0.085} \mathrm{O}_{3-\delta}$ samples synthesized by LRS are superior to those of both samples for the same compositions by SSR at any temperatures. The conductivities of $\mathrm{La}_{0.9} \mathrm{Sr}_{0.1} \mathrm{Ga}_{0.8} \mathrm{Mg}_{0.2} \mathrm{O}_{3-\delta}$ and $\mathrm{La}_{0.8} \mathrm{Sr}_{0.2} \mathrm{Ga}_{0.83} \mathrm{Mg}_{0.085} \mathrm{Co}_{0.085} \mathrm{O}_{3-\delta}$ samples synthesized by LRS are about twice and thrice as much as those of the samples for the same compositions synthesized by SSR (see Fig. 2b, 2e), respectively. From the XRD patterns (Fig.1a, 1b, 1e and 1h) and the results of relative density it can be seen that the $\mathrm{La}_{0.9} \mathrm{Sr}_{0.1} \mathrm{Ga}_{0.8} \mathrm{Mg}_{0.2} \mathrm{O}_{3-\delta}$ and $\mathrm{La}_{0.8} \mathrm{Sr}_{0.2} \mathrm{Ga}_{0.83} \mathrm{Mg}_{0.085} \mathrm{Co}_{0.085} \mathrm{O}_{3-\delta}$ samples synthesized by LRS show the similar purity and density to those of both samples for the same compositions by SSR. Therefore, the $\mathrm{La}_{0.9} \mathrm{Sr}_{0.1} \mathrm{Ga}_{0.8} \mathrm{Mg}_{0.2} \mathrm{O}_{3-\delta}$ and $\mathrm{La}_{0.8} \mathrm{Sr}_{0.2} \mathrm{Ga}_{0.83} \mathrm{Mg}_{0.085} \mathrm{Co}_{0.085} \mathrm{O}_{3-\delta}$ samples synthesized by LRS exhibit superior electrical properties to those samples by SSR possibly due to their unique microstructure formed in laser rapid sintering. In the laser synthetic route, the raw materials were heated to melt immediately upon illumination of the laser beam and formed a molten pool where the chemical reaction took place. The products solidified rapidly as the laser beam moved ahead. The sufficiently high temperature ensured sufficient melting of the raw materials and consequently rapid and uniform reactions. As the laser energy was absorbed by the top layer of the raw materials, heat transfer in a sample was mainly directed from the top surface to the bottom and also governed by the moving direction of the laser beam. The unique microstructures of the samples produced in the laser synthetic route can be attributed to the relatively oriented crystalline growth governed by heat transfer directions in the liquid droplet-like molten pool.

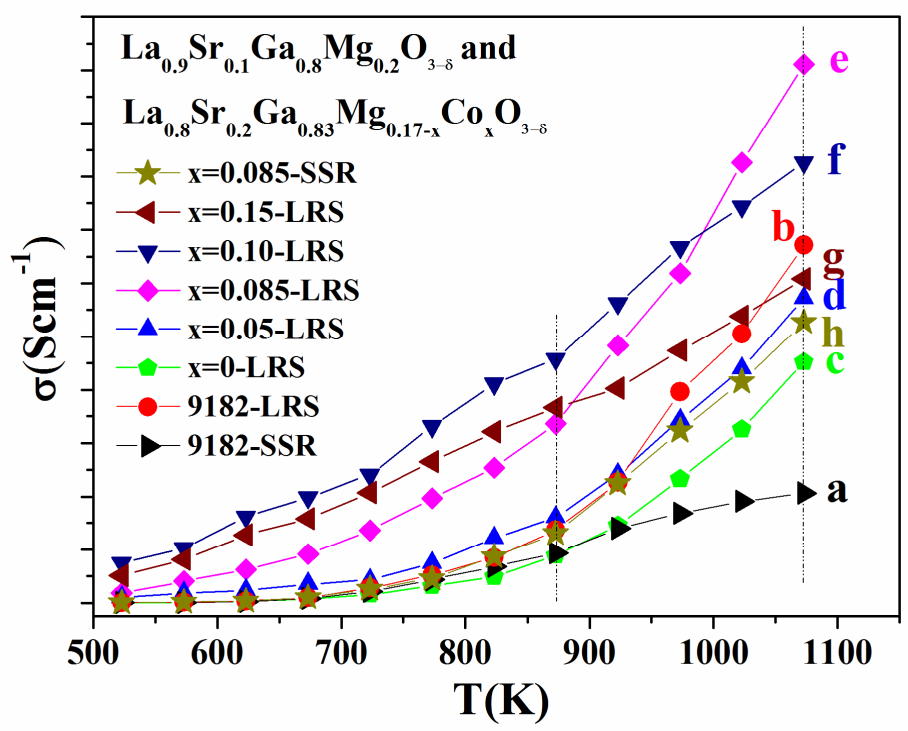

Figure 2. The total conductivities plots of $\mathrm{La}_{0.9} \mathrm{Sr}_{0.1} \mathrm{Ga}_{0.8} \mathrm{Mg}_{0.2} \mathrm{O}_{3-\delta}$ powders synthesized by (a) solid state reaction at respectively $1250^{\circ} \mathrm{C}$ for $10 \mathrm{~h}, 1500^{\circ} \mathrm{C}$ for $6 \mathrm{~h}$ and $1600^{\circ} \mathrm{C}$ for $2 \mathrm{~h}$ (SSR); (b) laser rapid sintering (LRS) with $1100 \mathrm{~W}$ laser powers at $1 \mathrm{mms}^{-1}$ scan speed, and $\mathrm{La}_{0.8} \mathrm{Sr}_{0.2} \mathrm{Ga}_{0.83} \mathrm{Mg}_{0.17-x} \mathrm{Co}_{x} \mathrm{O}_{3-\delta}$ samples by LRS; (c) $\mathrm{x}=0$; (d) $\mathrm{x}=0.05$; (e) $\mathrm{x}=0.085$; (f) $\mathrm{x}=0.10$; (g) $\mathrm{x}=0.15$ and (h) $\mathrm{La}_{0.8} \mathrm{Sr}_{0.2} \mathrm{Ga}_{0.83} \mathrm{Mg}_{0.085} \mathrm{Co}_{0.085} \mathrm{O}_{3-\delta}$ sample by SSR.

\section{Conclusion}

Laser rapid sintering (LRS) has been used for the synthesis of $\mathrm{La}_{0.9} \mathrm{Sr}_{0.1} \mathrm{Ga}_{0.8} \mathrm{Mg}_{0.2} \mathrm{O}_{3-\delta}$ and $\mathrm{La}_{0.8} \mathrm{Sr}_{0.2} \mathrm{Ga}_{0.83} \mathrm{Mg}_{0.17-\mathrm{x}} \mathrm{Co}_{\mathrm{x}} \mathrm{O}_{3-\delta}(\mathrm{x}=0,0.05,0.085,0.10,0.15)$ materials. It is shown that the laser rapid 
sintering method is suitable for rapid synthesis of $\mathrm{La}_{0.9} \mathrm{Sr}_{0.1} \mathrm{Ga}_{0.8} \mathrm{Mg}_{0.2} \mathrm{O}_{3-\delta}$ and $\mathrm{La}_{0.8} \mathrm{Sr}_{0.2} \mathrm{Ga}_{0.83} \mathrm{Mg}_{0.17-\mathrm{x}} \mathrm{Co}_{\mathrm{x}} \mathrm{O}_{3-\delta}$ with controlled compositions. It is found that the total conductivities of $\mathrm{La}_{0.8} \mathrm{Sr}_{0.2} \mathrm{Ga}_{0.83} \mathrm{Mg}_{0.17-\mathrm{x}} \mathrm{Co}_{\mathrm{x}} \mathrm{O}_{3-\delta}$ by LRS are obviously improved by Co doping, showing a general increase with the content $\mathrm{Co}$ except that for $\mathrm{x}=0.15$. The $\mathrm{La}_{0.9} \mathrm{Sr}_{0.1} \mathrm{Ga}_{0.8} \mathrm{Mg}_{0.2} \mathrm{O}_{3-\delta}$ and $\mathrm{La}_{0.8} \mathrm{Sr}_{0.2} \mathrm{Ga}_{0.83} \mathrm{Mg}_{0.085} \mathrm{Co}_{0.085} \mathrm{O}_{3-\delta}$ samples prepared by LRS give rise to better electrical properties with respect to that prepared by solid state reactions for the same compositions at any temperatures. The conductivities of $\mathrm{La}_{0.9} \mathrm{Sr}_{0.1} \mathrm{Ga}_{0.8} \mathrm{Mg}_{0.2} \mathrm{O}_{3-\delta}$ and $\mathrm{La}_{0.8} \mathrm{Sr}_{0.2} \mathrm{Ga}_{0.83} \mathrm{Mg}_{0.085} \mathrm{Co}_{0.085} \mathrm{O}_{3-\delta}$ samples synthesized by LRS are about twice and thrice as much as those of the samples for the same compositions synthesized by SSR, respectively. The improved conductivities of the samples by LRS is attributed to the unique microstructures of the samples generated during laser rapid solidification. Therefore, the laser rapid sintering technology can greatly improve the electrical properties of the sintered sample by generating the unique microstructures.

\section{Acknowledgements}

This work is supported by Henan Province College Key Scientific Research Project (No. 15A15008420) and the National Natural Science Foundation of China (No. U1404109 and 11504334).

\section{References}

[1] J.W. Fergus: J. Power Sources Vol. 162 (2006), p. 30

[2] S.M. Haile: Acta Mater. Vol. 51 (2003), p. 5981

[3] E. Gomes, F.M.B. Marques and F.M. Figueiredo: Solid State Ionics Vol. 179 (2008), p. 1325

[4] P. Datta, P. Majewski and F. Aldinger: Materials Chemistry and Physics Vol. 102 (2007), p. 240

[5] A. Inoishi, T. Sakai, Y.W. Ju, S. Ida and T. Ishihara: Int. J. Hydrogen Energy Vol. 39 (2014), p. 21352

[6] S. Li and B. Bergman: J. Eur. Ceram. Soc. Vol. 29 (2009), p. 1139

[7] M. Morales, J.M. Pérez-Falcón, A. Moure, J. Tartaj, F. Espiell and M. Segarra: Int. J. Hydrogen Energy Vol. 39 (2014), p. 5451

[8] Y.L. Zhai, C. Ye, J.Z. Xiao and L. Dai: J. Power Sources Vol. 163 (2006), p. 316

[9] D. Lee, J.H. Han, Y. Chun, R.H. Song and D.R. Shin: J. Power Sources Vol. 166 (2007), p. 35

[10] J. Zhang, E.J. Liang and X.H. Zhang: J. Power Sources Vol. 195 (2010), p. 6758 